\title{
THE NATURE OF THE ENGAGEMENT OF THE UNITED STATES IN THE SYRIAN CRISIS: A THEMATIC ANALYSIS
}

\author{
Zainaddin M. Khidhir \\ Department of International Relations, Corvinus University of Budapest, Hungary \\ ORCID iD: https://orcid.org/0000-0003-4041-3777 \\ zainaddin.mawlood@uor.edu.krd
}

\begin{abstract}
The complications of the Syrian crisis that has extended over six years are overseen on three distinct levels which are national, topographical, and global. A closer look at the situation in Syria in 2010/2011 will help explain why the regime has survived, the complexities of the situation in Syria, and what makes the search for a stable political settlement so difficult. The purpose of the present study is to highlight the nature of US engagement in the Syrian crisis which involves maintaining the US military presence for regional stability, ensuring the enduring defeat of ISIS, countering the future expansion of the Iranian influence and political settlement to the conflict, containing the Assad's regime in the interim. By outlining various threats, issues, assessing the Syrian conflict and its key actors, this paper seeks to explain the US response to the Syrian crisis on basis of thematic analysis. In conclusion, the United States' foreign policy has continued in a region vital to its national security interests due to available oil, its impetus to protect Israel, to support security by retaining military bases, to preserve the position of the protectorate of client states, and friendly regimes, and to resist Islamic movements and terrorism.
\end{abstract}

Keywords: Foreign Policy; Syrian Crisis; US Engagement; ISIS; Terrorism

\section{INTRODUCTION}

Syria has seen anti-government demonstrations erupt. Similar protests in the Middle East as a result of the Arab Spring-inspired these demonstrations. The Assad regime reacted violently to the peaceful demonstrations, exacerbating the situation. He used the security and intelligence services to disperse rallies and marches, often with live fire, and to apprehend dissidents (Khan and Khan 2017). Despite expectations, the Syrian system has withstood tireless pressing factors and surge from abroad for almost five years. A closer look at the situation in Syria in 2010/2011 will help explain why the regime has survived, the complexities of the situation in Syria, and what makes a stable political settlement so difficult (Ottaway 2015). Figure 1 shows that the areas of influence under Syrian opposition forces were significantly decreased between the years 2017 and 2020. 


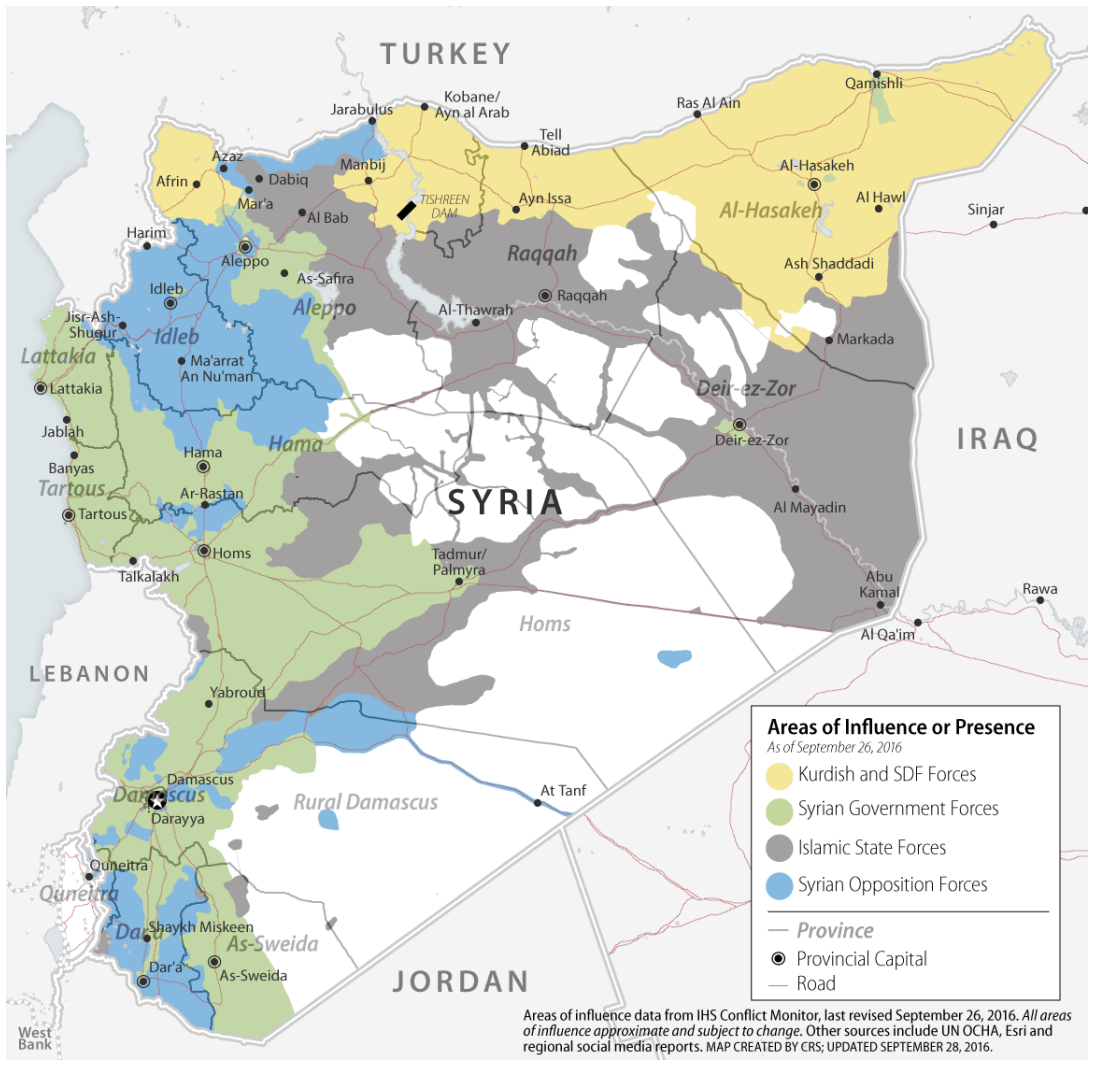

Figure 1: Areas of Influence or Presence (Source: Humud, Blanchard and Nikitin 2016)

The complication of the Syrian emergency that has extended over six years doesn't appear to be resolute at that present time or near future. It was overseen on three distinct levels which were national, topographical, and global (Rabinovich 2017).

\section{CONFLICT DIMENSIONS}

The Syrian civil conflict started in March 2011 in the southern city of Dera'a, roused by the Arab Spring which started a couple of months sooner in Tunisia and had shaken the establishment of a few Bedouin systems. The emergency could presumably have been contained had Bashar al-Assad and his lieutenants reacted gently and astutely to the underlying exhibits. All things being equal, they decided to subdue the dissent ruthlessly also, set off a steadily extending pattern of brutality that very soon turned into an undeniable common conflict. At the center of that war are various complaints against a bad and tyrannical system, generally significant of which is the Arab Sunni dominant part's refusal to acknowledge Alawite authority. 
The Alawites establish 12 percent of the province's populace and as a branch of Shiite Islam is not seen by traditionalist Sunnis as legitimate Muslims (Dostal 2014).

Regional Dimensions

Iran partakes straightforwardly in the common conflict and has utilized its Lebanese intermediary, Hezbollah, as a primary battling power as Bashar al-Assad's military has deteriorated in the course of the last not many a long time. Iran has additionally dispatched Syria Shiite warriors from Iraq and Afghanistan. Saudi Arabia doesn't take an interest straightforwardly in the battling however like different Sunni states it upholds a few resistance bunches with cash and weapons. Iran has extremely high stakes in the Syrian emergency. Under Bashar al-Assad, the Iranian-Syrian relationship has been changed from organization and partnership to reliance. As the Syrian common conflict heightened and the risk to the system's presence has developed, Iran had to expand its interest in Syria. It couldn't examine the possibility of losing its Syrian base, let alone of Syria going under Western or traditionalist Bedouin impact. On schedule, Iran and its intermediaries have assumed control over a huge part of the battle (Berti 2015).

Global Dimensions

With the flare-up of the common conflict in Syria, Russia's help for Bashar alAssad was discretionary. With China's assistance, it obstructed all moves in the Security Council coordinated against the system and its monstrosities. In the fall of 2015, Putin pushed ahead by choosing to mediate militarily in request to save al-Assad from military loss and dispatch its flying corps and air protection frameworks to northern Syria (Liff and Ikenberry 2014).

The Obama administration made plans to stay away from the 'no-fly zone' and different types of political associations in Syria. In 2011, the greater part of President Obama's senior helpers upheld the production of 'no-fly zone' or 'safe zones' and different types of inclusion, yet the president ruled against it (Manyin et al. 2012). The Syrian common conflict has also exacerbated the crisis presented to Europe by rushes of displaced people from African and Middle Eastern nations (Byman and Speakman 2016).

\section{OBJECTIVES OF THE STUDY}

The objectives of the present study are to provide a thematic analysis of US engagement in the Syrian crisis. The nature of US involvement and influence in Syrian conflicts is categorically divided into features like involves maintaining the US military presence for regional stability, ensuring the enduring defeat of ISIS, countering the 
future expansion of the Iranian influence and political settlement to the conflict, containing the al-Assad regime in the interim.

\section{THE NATURE OF US ENGAGEMENT IN THE SYRIAN CRISIS}

\section{Maintaining US Military Presence in Regional Stability}

The US is profoundly associated with wars that must be succeeded at the common military level, and where understanding the profound inside divisions and strains of the host country, and the pressing factors from outside states, are basic. Up until now, the United States has neglected to perceive the sheer size of the common issues it faces in leading military activities. It has neglected to comprehend the requirements to complete unrest in common military issues if it is to be fruitful in battling fizzled state wars that include significant counterinsurgency missions and dependence on have country powers. The US military job in Syria is a key for example, and it outlines plainly that any military exertion to try not to manage the full outcomes of the common side of a war can be a formula for disappointment (Cordesman 2017). In August 2013, as al-Assad's forces were defending, they used chemical weapons in alGhouta, a Damascus suburb (Aboultaif 2016). The West's inability to react quickly to alAssad's use of synthetic weapons aided the harsh repression of protestors (Eckert 2020). This occurred a few days after Obama's announcement that al-Assad would cross a red line if chemical weapons were used (Kfir 2016).

After US and UN investigators confirmed Syrian gas use, president Obama considered a military strike to act as a deterrent and a roadblock to Assad's use of chemical weapons (Kaphle 2014). Obama went to Congress to seek approval for a military strike. Before the vote, Russia negotiated a deal that allowed Syria to hand over its chemical weapons. On 21 September 2013, Syria agreed to its demands and handed over information about its chemical weapons to the UN, effectively putting an end to the threat of Western attacks (Escritt 2013). As indicated by certain examiners, the US international interests in the Middle East are to control the production and exchange of oil and gas items around there and to guarantee the assurance of ethnic and strict confinement Israel around there. That is the reason the US doesn't need an entire Syria that represents a danger to Israel's security. Since 2012, military and monetary help have been given to a few resistance powers around there. In 2016, the US set up an army installation in al-Tanf, close to the Iraq and Jordan line. At this base, the assailants of 'Megavir al-Tavra' were prepared by the US military. In 2012, the Kurdish People's Defense Unity (KPDU), a neighborhood Kurdish gathering in Syria, which has developed altogether with the assistance of the United States, has assumed responsibility for the northeastern pieces of the country. 
The United States has detailed that they have been furnished Kurds against ISIS warriors in Syria (Oner, Durmaz-Drinkwater, and Grant 2020). For a long time, the US and its allies have been fighting the Islamic State in northwest Syria, attempting to cut off the group's access to the Turkish border and advance toward Raqqah, the group's proclaimed capital. Islamic State power over the purported 'Manbij Pocket' the territory limited by Azaz in the west, the Turkish boundary in the north, al-Bab toward the south, and the Euphrates stream toward the east (Figure 2) filled in as the excess association point for the Islamic State to the rest of the world and gave a key stockpile and unfamiliar contender travel course (Erlich and Chomsky 2014).

On 17 September 2016, US military officials announced that they had halted a strike in eastern Syria after learning from Russia that the vehicles and personnel targeted were potentially vital to the Syrian military. According to Syrian and Russian officials, Syrian soldiers were killed and another 100 were injured in the attacks. Russia convened a Security Council crisis meeting to discuss the incident, which is the first time that US forces have been linked to the Syrian military since the country's dynamic activities began in September 2014 (Fischer 2014). However, despite their usefulness, these findings do not provide insight into how the fate of Syria's renowned US allies, the Syrian Kurds, could be simplified when enforcing the current foreign policy that aims to avoid direct military interference. It's also worth noting that the preceding findings contribute to an interpretation of possible reasons for the United States' withdrawal from Syria, however, fails to uncover any of the incidents that could have contributed to the country's previous ignorance of the crisis (Phillips 2016).

Psychological injustice and revolutionary fanaticism are both dangerous. Regardless of ISIS' defeat, psychological warfare also has a long way to go. Under the guise of jihad, revolutionary revolutionaries train warriors. The brain science of radicalism can be traced back to the Gulf War when most Middle Eastern countries were enraged by the US's successful contribution. Jihadism resurfaced to save the Muslim world from Western invaders. From one point of view, an individual's, a family's, and a state's vulnerability led to a decision based on unconstitutional coercion and fanaticism. On the other hand, the unsteady world of politics provides fertile ground for psychological oppression to develop. Revolutionary fanatics and oppressors motivated by fear are then ready to use religion as a political tool to achieve their goals. They have killed and wounded a large number of ordinary people and US troopers (Rasheed 2021).

Ensure the Enduring Defeat of ISIS

The emergence of ISIS and the active position of Kurdish power has influenced the depth of the US goal and dedication to maintaining the state structure in the region as defined by physical borders drawn a century ago. Although the US has long been 
concerned about the Arab Gulf states 'chequebook diplomacy', ${ }^{1}$ it is only now that these states are using military force on their own, even in ways that are uncoordinated with their conventional security guarantor (Mueller et al. 2017). According to estimates, the so-called Islamic State has lost roughly 45 percent of its territory in Iraq and 10\% in Syria (Kozaric 2017). Such major increases in military missions, in particular, are critical in reducing ISIS' ability to exercise complete control over its membership base, as well as its ability to finance itself unrestrictedly through the sale of oil, objects, slaves, and the burdening and coercion of money-related installments from its daily citizen population (Speckhard and Yayla 2016). Recently, US authorities have announced a significant decrease in the number of foreign warriors traveling to Iraq and Syria from 2000 to 500 per month, with some estimates falling as low as 200 (Kozaric 2017).

For more than 50 years, the United States has had a political, economic, and military relationship with the Central East (Altunısık 2013). Despite the public's fatigue with the dispute and growing support for a fantastic restriction strategy, direct US involvement in the district will continue in the foreseeable future. Regardless of the difficulties in recognizing (not to mention seeking after and accomplishing), the United States has numerous center interests in the Middle East, including the 'least bad option' in the Syrian popular conflict, the Israeli-Palestinian conflict, and the unwelcome tension between promoting democratization and power. These include preventing the rise of a local hegemon, nuclear expansion, and large-scale terrorist attacks on the region, as well as ensuring access to oil and the safety of provincial partners (Altunışık 2013).

These vested interests serve as a backdrop to the most serious regional threat to emerge in recent years: ISIS, or the Islamic State of Iraq and Syria. Fortunately, ISIS poses little threat to the United States' most vital territorial interests, such as preventing the rise of a provincial hegemon and the proliferation of nuclear weapons. The bad news is that ISIS poses a significant threat to some other US interests, including the stability of local allies and the prevention of psychological militant attacks (Nance 2016). Intelligence analysts came to know that ISIS has three faces, but somehow ISIS is at the same time is a rebel group, a state government, and an innovator association. Understanding and beating any one of these individuals is thought-provoking; efficiently addressing all three at once is almost dreadful given the tensions in main concern and strategies among them. The task turns out to be much more troublesome given that the US is far superior positioned to overcome a few parts of ISIS than others. The underestimation of ISIS will in this way require a multilateral, multi-stage exertion across various fronts: a conflict of bombs, a conflict of administration, what's more, a conflict of thoughts. I offer a progression of strategy suggestions for how these three isolated battles can be sought after in reciprocal style, instead of in detachment or

\footnotetext{
1 'Chequebook diplomacy' is a foreign policy which openly uses economic aid and investment between countries in bilateral relationships order to carry out diplomatic favors.
} 
inconsistency (Hüppi et al. 2016). Overcoming ISIS as a state necessitates something more than simply removing them from the control of the country. To ensure that the 'Islamic State' does not return and is not welcomed by people in the pounded provinces, competitive authority must be involved and won. Local governments must meet residents' basic needs, such as safety and transportation, as well as necessities such as employment, health care, and schools. The most important thing is that they should make civilians feel secure in this country, regardless of whether they are a minority ethnic or religious group. If governments fail to offer basic rights and need to citizens, affected people will become more vulnerable to extremist groups like ISIS, which promises safe streets, free schools, and an end to fraud in exchange for increased restrictions on liberty (Krause 2018).

In any case, the US can and should set the tone by offering political, financial, and military assistance to help authorize power-sharing arrangements both within and between Middle Eastern countries. The most significant obstacles to quality, systemic administration in the region are fights between gatherings and states over the circulation of assets and power. The US should provide momentum and international pressure to help territorial states enter and develop agreements that ensure that all ethnic and religious networks have a seat at the table and a stake in the region. They can also collaborate with key allies like Saudi Arabia, Turkey, and Egypt, as well as key adversaries like Russia and Iran, to develop concrete concessions to handle global knowledge exchange and authoritative reaches. Conflicts and conflicts will continue, but the costs of endless intermediary wars that do little but strengthen a widespread threat like ISIS should encourage these interactions to move toward a more secure territorial appeal (Silverstone 2018).

ISIS can be defeated, but only with strong provincial alliances and if the war isn't entwined with larger initiatives of foreign-imposed regime change and democratization, which have had a bleak history and a bleak future. The secret to defeating ISIS is to recognize and recognize its three faces, as well as to exploit the vulnerabilities that such a dynamic organization poses (Blumenthal 2020).

Counter the Future Expansion of Iranian Influence

Iran has been able to formalize and expand Shi'a unfamiliar warrior organizations all over the region as a result of the conflicts in Syria and Iraq. Shi'a assailants from Syria, Lebanon, and Iraq are transforming into a 'Hezbollah-style' organization loyal to Iran and ready to fight alongside Iranian soldiers and guides. The Afghan and Pakistani Khomeinist networks were then converted to include a large number of candidates for use as stun troops in war zones spanning the Middle East and South Asia (Daraghi 2017). The Obama administration's Presidential Policy Guidance (PPG) paper, titled 'Methodology for Approving Direct Action outside the United States and Spaces of 
Active Hostilities', outlined a plan for strikes outside of spaces of complex challenges, which include Afghanistan, Iraq, Syria, and a few Libyan spaces for short periods. Jones (2017), described the White House Deputies Committee meetings were crucial for obtaining approval for such assaults regularly.

In either case, groups like ISIS have become increasingly decentralized and adaptable, requiring the US to be equally efficient and adaptable. The fall of oil costs from mid-June 2014 (60\% tumble from the pinnacle cost) contrarily influenced the Iranian oil industry (Farzanegan and Parvari 2014). The low costs couldn't make it workable for the nation to profit from the extension of oil sends out after the atomic understanding, however much the benefit would have been under before conditions. Saudi Arabia, the philosophical and international adversary of Iran, applies a huge impact on the cost of oil and the lasting low-value level serves the interest of the Kingdom against Tehran (Farzanegan and Parvari 2014). Without tremendous fare earnings, it makes the homegrown capital amassing unthinkable, along these lines hindering the recuperation of the Iranian hydrocarbon area) Because in the postsanctions era the Iranian government has not delivered the expected high economic results yet (Davig et al. 2015). The leadership has been facing criticism from the proponents of the political and economic isolation of Iran.

To resolve the existing shortcomings and potential dangers in the Iranian hydrocarbon sector, the Iranian government must make improvements to the infrastructural foundation and institutional foundation of oil and gas companies, as well as address the global impact on these critical areas. When in doubt, Iran should take advantage of its current qualities and anticipated freedoms to fully solve domestic and global oil and gas problems (Dudlák 2018).

Iran appears to be making strides toward greater energy success. Somehow recently, there is a reasonable shift from the philosophical contemplations to a more sober-minded methodology in the administration of the Iranian economy and the essential assets. Under these conditions, building trust is fundamental, however, it is a more extended interaction by its temperament. This suffering change in Iran may be a great feature of how a shut economy wealthy in hydrocarbon assets can change its philosophical also, political design bit by bit from the inside. Outside influences, in addition to internal practices, continue to play a significant role in this period of transition, and in this context, the global community's responsibility to support Iran's reformist plan is crucial. In light of everything, it merits keeping just the lower assumptions concerning the impending creation blast of the Iranian hydrocarbon industry has suffered. Because of external market proclivities (low oil value, oversupply on the horizon) and inward reallocation of monetary capital. Practically speaking, it implies that both the augmentation of fare limit and the contribution of worldwide organizations will happen in a continuous, managed way, wherein every one of the interests of significant Iranian political and monetary partners will be thought of among 
the invested individuals, the most plausible situation proposes a sluggish and ceaseless change in the Islamic Republic's oil and gas industries (Dudlák 2018).

\section{Political Settlement of the Conflict in the Assad's Regime}

Syria's civil war is now in its seventh year, with a wide range of public and international events. Critically, no group is in a position to take control of the entire world. This document contains recommendations for efforts at stabilization. There is a growing recognition that the Assad regime cannot be overthrown and that efforts to find a diplomatic solution should take this into account. The focus has shifted to methods for reducing conflict and planning for reform talks (Heydemann 2020).

The Syrian dispute is a multi-layered one involving multiple entertainers, rather than a war between two gatherings. There are threats between various Syrian resistance gatherings (eminently conservatives and radicals), with the Kurds, with Islamic State, and between fanatic gatherings (ISIL just as there is a 'key' struggle between the al-Assad regime and Syrian resistance gatherings, with the Kurds, with the Islamic State, between fanatic groups (including ISIL and Jabhat al-Nusra), and an intermediary fight between Russia, Iran, and Hezbollah, which support the al-Assad regime, and the West, which sponsors' moderate resistance groups. Saudi Arabia, the United Arab Emirates, Qatar, and Turkey are also included, supporting various Syrian resistance groups, including fanatic gatherings - the first two nations are primarily moving fanatic gatherings in the south, while the third and fourth nations are primarily moving fanatic gatherings in the north (Pawlak 2017).

Iran is adamant about preserving the regime, fearing that al-Assad's removal would lead to parallel efforts in Iran to destabilize the Islamic Republic (Jenkins 2013; Kodmani 2015). Iran would also lose a major ally in the area. Iran has pressed Hezbollah to assist Syria's army, much as it has gathered Shi'a volunteers in Iraq and Lebanon.

The West is reluctant to provide generous military assistance to opposition groups for fear of Assad being replaced by a radical Islamist government and advanced weapons falling into the hands of radical groups and being used to attack the West (Jenkins 2013; Kodmani 2015). The dispute has disintegrated government institutions, including the nation's outfitted powers, which have been replaced by a web of increasingly self-governing neighborhood elements. A majority of the volunteer forces fighting to protect the regime are not under direct government supervision (Jenkins 2013). This has implications for any potential settlement, as there are several independent military and criminal gatherings, regardless of whether the military is killed.

The EU made remarks like "President Assad must step aside to allow a political transition to take place in Syria" from August 18th to the end of 2012 (Turkmani and Haid, 2016). As a result, for Russia, the tradeoffs associated with power-sharing are distinct from those associated with the power distribution regime of Bashar al-Assad. 
The United Nations Security Council adopted Resolution 2254 on 18 December 2015, which alludes to a temporary administering body but also calls for "sound, inclusive, and nonsectarian administration", the drafting of a new constitution, and UNmanaged decisions. The UN is secretly de-emphasizing aggressive conflicts about how to decode temporary language acquired in 2012 by shifting focus to coincidental political courses of action, thus opening the possibility of a peaceful relationship that allows al-Assad to stay in power (Lund 2017).

There are huge schisms over the al-Assad regime, with some (such as the Syrian opposition, the US, the EU, and most Arab states) demanding his removal and others (such as Iran and Russia) finding the structure to be equally essential. So far, finding a reasonable middle ground on al-Assad's future has proven difficult. There appears to be growing recognition, based on rationality, of the al-Assad regime's continued presence among global partners. Nonetheless, as Kodmani points out, "there is a difference between maintaining Assad and his system as is, and maintaining Assad and his system as is, on the one side, and keeping Assad in control for a limited time before his flight can be booked as part of a pre-planned popularity-driven loop based on sacred components, on the other" (Ibrahim 2017).

It was determined that al-Assad could not consolidate his authority over the entire country, and given the disparities in positions of anti- and pro-government forces on a variety of issues, it is unclear if Syria can be safeguarded in its current form. Future efforts at post-conflict reconstruction in Syria may be based on the simple assumption that 'Syria' no longer has a political substance that can be resurrected in any meaningful form (Tuck 2016). Whatever the case may be, the disintegration or secession of Syria poses a significant threat to the Middle East's overall power. The agreement could now include maintaining Syria's current structure along with significant political and monetary decentralization, as well as a special status for Kurdish areas (however this last point could confront resistance from Turkey) (Zaarour 2018).

\section{CONCLUSION}

The economic and political presence of the United States in the Middle East constituency before, during, and after World War I and World War II aids in understanding how the United States developed itself in the region and what its goals were following its manifestation. The current article also emphasizes the US critical interests in the Middle East, including ensuring deliberate access to oil in the Gulf region, promoting and defending Israel's supremacy, maintaining US military bases, securing client-states and supportive regimes, and combating Islamic movements, and terrorist organizations. The synthesis of research based on this literature review shows that the United States foreign policy has continued in a region vital to its national security interests due to available oil, its impetus to protect Israel, to support security by 
retaining military bases, to preserve the position of the protectorate of client states and friendly regimes, and to resist Islamic movements and terrorism. These five forces have pushed US decision-makers to take control of the area, and they continue to be essential to the US today.

Students and scholars of international affairs need to consider the history of the Middle East importance, as well as insight into the motivations and desires of American decision-makers, to influence and establish policy (Al Sarhan 2017). 


\section{REFERENCES}

1. Aboultaif, E. W. 2016. 'Regional and International factors that prolong the Syrian Crisis', Syria Studies, 8(2), pp. 1-11.

2. Al Sarhan, A. S. 2017. 'United States Foreign Policy and the Middle East', Open Journal of Political Science, 7(04), p. 454.

3. Altunışık, M. B. 2013. 'The middle east in Turkey-USA relations: managing the alliance', Journal of Balkan and near eastern studies, 15(2), pp. 157-173.

4. Berti, B. 2015. 'The Syrian refugee crisis: Regional and human security implications', Strategic Assessment, 17(4), pp. 41-53.

5. Blumenthal, M. 2020. The Management of Savagery: How America's National Security State Fueled the Rise of Al Qaeda, ISIS, and Donald Trump. Verso.

6. Byman, D. and Speakman, S. (2016) 'The Syrian refugee crisis: Bad and worse options', The Washington Quarterly, 39(2), pp. 45-60.

7. Cordesman, A. H. 2017. 'Stability Operations in Syria', Military Review, 2.

8. Daraghi, B. 2017. 'Inside Iran's Mission To Dominate the Middle East', Buzzfeed, July, 30.

9. Davig, T. et al. 2015. 'Evaluating a year of oil price volatility', Federal Reserve Bank of Kansas City, Economic Review, 100(3), pp. 5-30.

10. Davig, T., Melek, N.Ç., Nie, J., Smith, A.L. and Tüzemen, D., 2015. Evaluating a year of oil price volatility. Federal Reserve Bank of Kansas City, Economic Review, 100(3), pp.5-30.

11. de la Unión Europea, C. (no date) 'European Council-Council of the European Union'. Recuperado el.

12. Dostal, J. M. 2014. 'Analyzing the domestic and international conflict in Syria: Are there lessons from political science?', Syria Studies.

13. Dudlák, T. 2018. 'After the sanctions: Policy challenges in the transition to a new

14. Eckert, A. E. 2020. 'The Responsibility to Protect in the Anarchical Society: Power, Interest, and the Protection of Civilians in Libya and Syria', Denver Journal of International Law \& Policy, 41(1), p. 8.

15. Erlich, R. W. and Chomsky, N. 2014. Inside Syria: The backstory of their civil war and what the world can expect. Prometheus Books Amherst, NY.

16. Escritt, T. 2013. 'Syria meets deadline for chemical weapons disclosure', Reuters. Retrieved, 23.

17. Farzanegan, M. R. and Parvari, M. R. 2014. 'Iranian-Oil-Free Zone and international oil prices', Energy Economics, 45, pp. 364-372.

18. Fischer, H. 2014. A guide to US military casualty statistics: Operation inherent resolve, operation new dawn, operation Iraqi freedom, and operation enduring freedom. Congressional Research Service Washington, DC. 
19. Heydemann, S. 2020. 'The Syrian Conflict: Proxy War, Pyrrhic Victory, and Power-Sharing Agreements', Studies in Ethnicity and Nationalism, 20(2).

20. Hüppi, R. et al. 2016. 'N use efficiencies and N2O emissions in two contrasting, biochar amended soils under winter wheat - Cover crop - Sorghum rotation', Environmental Research Letters, 11(8). doi: 10.1088/1748-9326/11/8/084013.

21. Ibrahim, A. 2017. 'Ending the Syrian civil war: Is there a federal solution?', Geopolitics, History, and International Relations, 9(2), pp. 141-166.

22. Jenkins, B. 2013. The Dynamics of Syria's Civil War. Perspectives, RAND. http://www.rand.org/content/dam/rand/pubs/perspectives/PE100/PE115/RAND PE115.pdf

23. Jones, S. G. 2017. 'Managing the Long War', US Policy toward Afghanistan and the Region. RAND Corporation.

24. Jones, S.G., Dobbins, J., Byman, D., Chivvis, C.S., Connable, B., Martini, J., Robinson, E. and Chandler, N., 2017. Rolling Back the Islamic State. Rand Corporation.

25. Kaphle, A. 2014.'Timeline: Unrest in Syria', The Washington Post.

26. Kfir, I. 2016. 'NATO and Putin's Russia: Seeking to balance divergence and convergence', Comparative Strategy, 35(5), pp. 447-464.

27. Khan, H. U. and Khan, W. 2017. 'Syria: History, The Civil War and Peace Prospects.', Journal of Political Studies, 24(2).

28. Kodmani, B. 2015. Syrian Voices on the Syrian Conflict: A Solution for Syria. Norwegian Peacebuilding Resource Centre(NOREF). http://noref.no/var/ezflow_site/storage/original/application/fde6cee7be339020cd 79be5bf1f97cbe.pdf

29. Kozaric, E., 2017. Exploring the demand side of foreign rebel recruitment: a comparative case study of AI Qaeda in Iraq (2004-2008) and the Islamic State (2012-2016).

30. Krause, P. 2018. 'A State, an Insurgency, and a Revolution: Understanding and Defeating the Three Faces of ISIS', The Future of ISIS: Regional and International Implications, pp. 223-246.

31. Liff, A. P. and Ikenberry, G. J. 2014. 'Racing toward tragedy?: China's rise, military competition in the Asia Pacific, and the security dilemma', International Security, 39(2), pp. 52-91.

32. Lund, A., 2019. From cold war to civil war: 75 years of Russian-Syrian relations. Stockholm: Swedish Institute of International Affairs.

33. Manyin, M. E. et al. 2012. 'Pivot to the Pacific? The Obama Administration's" Rebalancing" Toward Asia', in Library of Congress Washington DC Congressional Research Service.

34. Mueller, K.P., Wasser, B., Martini, J. and Watts, S., 2017. US Strategic Interest in the Middle East and Implications for the Army. RAND Arroyo Center Santa Monica Ca Santa Monica United States. 
35. Nance, M. 2016. Defeating ISIS: Who they are, how they fight, what they believe. Simon and Schuster.

36. Nance, M., 2016. Defeating ISIS: Who they are, how they fight, what they believe. Simon and Schuster.

37. Oner, A. C., Durmaz-Drinkwater, B. and Grant, R. J. 2020. 'Precarity of refugees: the case of Basmane-İzmir, Turkey', Journal of Ethnic and Migration Studies, pp. $1-20$.

38. Ottaway, M. 2015. 'Learning from Sykes-Picot', Middle East Program Occasional Paper Series. Washington, DC: Wilson Center.

39. Pawlak, P. 2017. Mapping the future of Syria: State of Play and options. European Parliamentary Research Service.

40. Phillips, C. 2016. The battle for Syria: International Rivalry in the new Middle East. Yale University Press.

41. Rabinovich, I. 2017. 'The Syrian Civil War as a Global Crisis', Sfera Politicii, 25(191192), pp. 44-48.

42. Rasheed, A.A., 2021. Strategic Shifts During Obama's Tenure and its Effects on Iraqi National Security. Regional Studies Journal, 15(47).

43. Silverstone, S. A. 2018. From Hitler's Germany to Saddam's Iraq: The Enduring False Promise of Preventive War. Rowman \& Littlefield.

44. Speckhard, A., Shajkovci, A. and Yayla, A.S., 2016. Defeating ISIS on the battleground as well as in the online battle space: Considerations of the "new normal" and available online weapons in the struggle ahead. Journal of Strategic Security, 9(4), pp.1-10.

45. Tuck, H., Silverman, T., and Smalley, C., 2016. "Shooting in the right direction": Anti-ISIS Foreign Fighters in Syria. Institute for Strategic Dialogue.

46. Zaarour, B. 2018. 'Turkish Foreign Policy Toward Syria After 2011: A New Regional Order and the Role of Political Islam'. 